\title{
Organização Internacional do Trabalho *
}

\author{
ESTANISLAu Fischlowitz.
}

No momento em que a O.I.T. perfaz o quadragésimo aniversário de sua vida (1919-1959) parece justificar-se uma análise retrospectiva do funcionamento dessa orgavização internacional, uma das mais antigas existentes no momento, e, ademais, único organismo que, criado no fim da primeira guerra mundial, resistiu vitoriosamente ao impacto das agudas crises verificadas nas relações internacionais nestes últimos 40 anos.

\section{ORIGEM DA O.I.T.}

Cumpre salientar que não é nova nem original a idéia de fomento internacional do progresso social.

Vale a pena mencionar o fato de que muito tempo antes da criação da O.I.T. (1) primeiro organismo de direito internacional público dêsse gênero. funcionavam certas associações privadas de indole internacional, sobretudo a dedicada ao direito tutelar do trabalho. (2)

O principal mérito pela radical inovação sócio-juridica, relacionada com a constituição de uma entidade organizacional pública ad hoc, com atribuições amplas e incisivas : decisão da Conferência preliminar de Paz de 11 de abril de 1919, a assinatura do Tratado de $\mathrm{Paz}$ de Versailles, em 28 de junho de 1910 e a realização da primeira sessão (de Washington) da Conferência Internacional do Trabalho: 29 de outubro até 29 de novembro de 1919 , deve-se. de um modo preponderante, à iniciativa da delegação britânica à Conferência de Paz ("premier" Lloyd George, em cumprimento às proposições nesse sentido das organizações sindicalistas inglêsas, como, aliás, também americanas e centro-européias).

(*) Capitulo, consideràvelmente abreviado e revisto do estudo intitulado "Regulamentação Internacional das Questões Sociais", a ser publicado em breve.

(1) Parte XIII do 'Tratado de Paz de Versailles (Art. 387-427); veja-se também as disposições correlativas incluidas no art. 23 do Pacto da Sociedade das Nações.

(2) Associação Internacional para a Proteçâo dos Trabalhadores, constituida, com sede em Brasiléia (Suiça), em $1^{\circ}$ de maio de 1901, que contou, na sua fase mais adiantada, com 15 seções nacionais, e que promoveu a conclusăo de duas convenções internacionais, adotadas pela Conf rência de Berna de 1906: sĉbre a proihição do trabalho noturno das mulheres e do uso de fósforo branco em vários processos industriais. 


\section{OBJETIVOS DA O.I.T.} nentes.

Como é natural, não podem ser considerados como estáveis e perman

Na sua constante e flexivel revisão têm que obedecer, por um lado, às profundas alterações do panorama econômico-social, ocorridas desde 1919 até 1959; por outra parte, acusam influência fatal da distância, ainda muito maior, que separa os conceitos político-sociais, peculiares dessas duas épocas.

Em 1919 prevalecia ainda a crença na onipotência das realizações reformadoras da legislação de trabalho. A principal fôrça motriz, que inspirava as obras de progresso social, foi o socialismo democrático, anterior à consolidação do comunismo totalitário e ao advento das correntes nazi-fascistas.

A iegislação social continuava orientada no sentido meramente assistencial, distributivo e tutelar. Os responsáveis pela mesma não chegaram ainda à compreensão da intima correlação entre os elementos econômicos e sociais da atuação do Estado intervencionista, que deviam encontrar, muito mais tarde, ampla expressão na doutrina keynesiana da política econômica, como também, vice-versa, nas medidas econômicamente mais construtivas da política social. A luta de classes, com separação nítida dos antagônicos interêsses do patronato e do assalariado, estava sendo considerada como base permanente e inalterável das relações sociais. Apenas 30 anos depois, devia sur!̣ir, em conexão com várias inovações tecnológicas, a campanha de produtividade, construindo novas pontes acime dêsses supostos abismos interclassistas. Não é mais segrêdo para ninguém que o novo e particularmente poderoso ciclo da revolução industrial dos últimos anos (automatização, novas fontes de energia, eletrônica, etc.) tende a levar, fatalmente, à revisão das finalidades e funções do Estado de Bem-Estar Social, que não foi possivel sequer imaginar no fim da primeira querra mundial.

Enfin, ao lado da bifurcação do mundo em dois mundos, o de livre empreendimento e o de economia socialista, subdivisão, naquele momento, apenas em estágio incipiente, delineiam-se, atualmente, os contrastes, cada vez mais agudos, entre as partes subdesenvolvidas e econômicamente valorizadas da terra, que, há quarenta anos, existiram apenas em estado latente, sem justificar ainda esforços conscientes no sentido da supressão ou diminuição substancial dos desniveis de existência daí resultantes.

E' verdade que, tanto no mundo de 1919 como no de 1959, há, em consonância com a acertada definição do Preâmbulo da Constituição da O.I.T.:

"condições de trabalho que implicam para com um grande número de pessoas, injustiça, miséria e privações, e que engendram tal descontentamento que ameaçam a paz e harmonia universais", sendo "urgente melhorar essas condições".

Não ialtam, com efeito, no atual mapa mundi, a despeito do tremendo progresso tecnológico e do conseqüente incremento do poderio produtor. industrial e agrícola, as manchas negras de fome, miséria e pobreza, desem- 
prêgo e demais formas de insegurança de existência e de seus níveis subhumanos. Se a distribuição geográfica dêsses fenômenos apresenta, em confronto com a situação de 1919 . diferenças notáveis, não parece de modo algum certo, se a sua frequiência e gravidade, encaradas globalmente, tenham, reste periodo, diminuído consideràvelmente.

Seja como fôr, aumentaram muito, nesse tempo, sem dúvida alguma, as pressões sociais, considerando-se, geralmente, as referidas condições, como incompativeis com os requisitos máximos de justiça social e com os direitos elementares humanos.

Pois bem, à luz das atuais, infinitamente mais ampliadas e diversificadas, responsabilidades e funções da política social, parecem obsoletas, fragmentárias e ábsolutamente precárias - de vez que superadas pelo curso dos acontecimentos - as metas do progresso social, indicadas, aliás, sòmente a título exemplificativo, pelo Preâmbulo da Constituição da O.I.T.

Entretanto, é com muita razão que não se cogitou da revisão dessas normas meramente programáticas, (3) o que tornaria necessária a permanente e tècnicamente difícil readaptação flexível dos objetivos da Organização aos novos fatos e às novas idéias, que, num ritmo crescente, modificam os propósitos filosóficos, a órbita e os meios de ação da politica social.

Foi.com muito acêrto que, sob a forma de uma simples resolução, denominada "Deciaração relativa aos propósitos e objetivos da O.I.T.", aprovada pela Conferência de Filadélfia de 1944 (4), portanto na fase final da segunda guerra mundial, e anexa à Constituição, foi feita uma tentativa no sentido de redefinir as principais diretrizes do programa da O.I.T., sem tocar, todavia. a sua formulação nos textos constitucionais de 1919.

Na nova interpretação dos princípios básicos da O.I.T., consubstanciada na Declaração de Filadélfia, dois aspectos parecem justificar exame mais atento.

Em primeiro lugar, a tentativa no sentido de reafirmar os direitos humanos, e que, em 1948, encontrou sua expressão mais solene na famosa "Declaraçâo Universal dos Direitos do Homem". (5)

E, por sua vez, a definição muito ampla das atribuições da O.I.T., extensiva até à apreciação das providências da politica econômica e financeira é corroborada por vários pareceres consultivos ("Avis") da Côrte Perıianente de Justiça Internacional.

(3) Convém realçar que a constituição, com a sua redação original de 1919, foi submetida, nesse meio tempo, quatro vêzes, à revisão, mediante emenda de 1922 (que entrou em vigor em 4 de junho de 1934) e por meio dos "instrumentos de emenda" de 1945 (vigência $\mathrm{cm} 26$ de setembro de 1946), de 1946 (20 de abril de 1948) e de 1953 (20 de maio de 1954). Contudo, tôdas essas emendas referem-se apenas aos aspectos de procedimento ou ampliam a composição dos órgãos da O.I.T., sem dizer respeito a seus objetivos e finalidades.

(4) Outro importante complemento das bases juridicas da O.I.T. constitui o acôrdo entre as Nações Unidas e a O.I.T., celebrado, em consonância com o art. 57 da Carta das Nações Unidas. em 30 de maio de 1946. Esse acôrdo (20 artigos) não trás, porém, muita coisa nova, salvo no que diz respeito aos detalhes administrativos do mecanismo internacional.

(5) "Declaração Universal dos Direitos do Homem" de 10 de dezembro de 1948. 


\section{MECANISMO ORGANIZACIONAL DA O.I.T.}

\section{A. Tripartidarismo}

O que sc destaca geralmente, como particularmente peculiar da estrutura dessa orgjanização é o caráter tripartidário de todos os seus órgãos, dos quais participam, em pé de igualdade, ao lado dos representantes dos governos, os porta-vozes das duas classes sociais: da patronal e da trabalhadora.

A O.I.T. é, com efeito, o único organismo oficial internacional, em cujos trabalhos tomam arte ativa os representantes do "capital" e do "trabalho" não apenas com caráter consultivo, como costuma acontecer em outros organismos, mas, sim, com os plenos direitos e obrigações que competer! aos delegados governamentais.

Cumpre adiantar que, na prática extra-juridica, firmada durante quarenta anos de operação dessa organização internacional, a subdivisão dos órgãos da O.I.T. em três grupos distintos, fechados e autônomos, se acentuou, com o tempo, ainda muito mais, manifestando uma rigidez que não se evidencia nos textos constitucionais daquela organização.

Como ć natural, ao passo que acusa certas lacunas a unidade e coesão do grupo governamental, em que aparecem os inevitáveis contrastes verticais entre os interêsses nacionais dos respectivos paises, elas orientam, de um modo geral, o comportamento solidário dos dois demais grupos.

$\mathrm{Na}$ verificação dos mandatos dos delegados dos trabalhadores que, juntamente com os delegados patronais e segundo com o art. $3^{\circ}, \S 5^{\circ}$ da Conistituição, têm que ser nomeados, "de acôrdo com as organizações profissionais mais representativas de empregadores e trabalhadores..., sempre que tais organizações existam no pais de que se trata», manifestam-se, com muita treqüéncia, nas sessões anuais da C.I.T., agudos choques, provenientes da estrategia e tática política das organizações sindicalistas de âmbito mundial.

Não nos parece absolutamente imprescindivel examinar nesta altura os "prós" e os "contras" da original solução encontrada, nesse particular, pelos autores da Constituição da O.I.T. Apresenta, de certo, a notável varitagem de associar às atividades da organização as principais classes sociais em que se subdivide a organização da moderna sociedade industrial. Tudo nos leva a crer que o rendimento de uma entidade de indole tradicional diplomática seria no setor em foco, inferior as resultados do funcionamento da orçanização tripartidária dêsse tipo. A composição acima aludida da Conferência Internacional de Trabalho the confere certas características aparentes de parlamento mundial de trabalho, que não podem ser consideradas indiferentes sob o prisma do prestígio que conquistou na ampla arena internacional.

Contudo, procurando-se balancear eqüitativamente os lados fortes e fracos dessa fórmula, é mister tornar patentes várias deficiências inseparáveis da mesma. Em primeiro lugar, tende a diminuir, no panorama social atual, a oposição das fôrças sociais antagônicas, evidenciada pela organização 
profissional separada das classes patronal e trabalhadora. A formação dessas classes, muito acentuada na órbita da economia industrial, perde a sua rigide: clássica na economia agropecuária, a que se estendem, cada vez mais, as atribuições da O.I.T., e em que têm ainda sempre posição predominante os grupos econômicamente ativos, independentes e autônomos da populaçã') rural, com elevada freqüência dos grupos intermediários, que se colocam entre os socialmente dependentes e independentes, grupos êsses, na sua maioria, econômicamente débeis e desfavorecidos.

\section{B. "Crise soviética" na O.I.T.}

Entretanto, o que provocou a crise aguda que estourou em Genebra, na última década, em tôrno do tripartidarismo da O.I.T. - e que dificilmente pode ser considerada como resolvida definitivamente, de uma vez para sempre, através da adoção, pela XLIII Sessão de junho de 1959, de uma solução provisória, de emergência - relaciona-se com a aplicação das referidas regras à representação dos paises de economia socialista da órbita soviética:

No intuito de alcançar, por razões óbvias, a almejada universidade, a O.I.T. incluiu entre seus paises-membros nada menos de 9 países integrados nesse bloco, também mediante a participação autônoma da Ucrânia e Bielorússia, por enquanto, sem adesão de mais 4 repúblicas comunistas restantes (China popular, Coréia, Vietnam do Norte e Alemanha "democrática").

A O.I.T. que, no período de sua org̣anização inicial, em 1919, estava composta de nada mais de 49 paises, atingiu, em 1959, o número impressionante - embora ainda distante do total teórico! - de 80 países-membros, dos quais 29 europeus, 22 americanos, 17 asiáticos, 10 africanos e 2 australianos $; 6)$

No momento em que quase um têrço da população mundial se encontra nos países do grupo comunista, são evidentes as vantagens que proporciona a ampliação da órbita da organização de cooperação internacional social aos referidos naises, que procuram uma solução da questão social, diferente da pleiteada pela política social dos países democráticos de livre empreendimento.

Entretanto, a plena integração dos países comunistas nas atividades da Organização Internacional do Trabalho fêz surgir tôda uma série de dificuldades da mais diversa ordem.

A Organização Internacional do Trabalho baseia-se no pressuposto tácito e implicitamente aceito na sua constituição, de acôrdo com a qual, na sociedade de todos os paises-membros existem as duas referidas classes sociais, livres e autônomas, que gozam de uma certa liberdade e indepen dência com relação a seus respectivos governos.

(6) Quanto à filiação dos paises à O.I.T., prevalecem as seguintes regras : Fora dos países que já pertenciam à mesma a $1^{2}$ de novembro de 1945 , pode tornar-se, automàt:camente, membro daquela Organização qualquer Estado-Membro das Nações Unidas, bastando para tal efeito sua aceitação formal das obrigações consubstanciadas na sua constituição, assim como qualquer Estado que, embora não pertencendo às Nações Unidas, comunique à referida declaração, desde que tenha a sua admissão aprovada por dois têrços dos delegados à Conferência, assim como por dois têrços dos delegados governamentais ali representados. 
Ora, êsse pressuposto não corresponde de modo algum à realidade na U.R.S.S. c nos demais países de economia socialista e organização soviética dos podêres públicos.

Como é óbvio, quanto à representação do patronato, não se poderia sequer imaginar a existência na U.R.S.S. das organizações representativas que congregariam os porta-vozes da gerentocracia soviética, em última análise, parte integrante do funcionalismo público, apenas distanciada dos seus demais grupos pelas funções específicas de caráter econômico que desempenha.

Contràriamente às aparências meramente terminológicas, não apresenta, aliás, diferenças acentuadas a situação encarada sob êsse ponto de vista, dos trabalhadores organizados em uniões sindicais dentro da órbita da sovietocracia.

Não pode, pois, causar espécie o fato dos representantes pseudo-classistas Soviéticos serem considerados como corpo estranho dentro dos grupos solidários e coesos da organização genuina de ambas classes em Genebra, o que estava provocando permanentes atritos na designação dos representantes comunistas para várias comissões e órgãos especificos da O.I.T. pelos respectivos grupos, e, particularmente, o patronal.

Não nos parece necessário apreciar, em maiores pormenores, a fórmula de compromisso, meramente político, encontrada, nesse particular, depois de vários anos de marchas e contramarchas, na sessão da Conferência Internacional do Trabalho de 1959, apenas mediante uso de alguns expedientes: podêres entregues à comissão especializada, integrada opr três representantes do poder judiciário, no que diz respeito à integração nos diversos órgãos da Conferência dos representantes comunistas pelos respectivos grupos, o que, na prática, visa os direitos reservados aos "empregadores soviéticos". (7)

\section{Representação dos paises de "maior" e "menor" importância industrial.}

Outro problema ainda se relaciona com a notória divergência entre (a) a paridade formal de todos os paises, qualquer que seja o seu tamanho, importância politica e potencial econômico e $(b)$ a concessão de alguns privilégios específicos, na posição cabivel nos referidos órgãos, aos países de maior relevância ou "de mais extensos interêsses".

Merece ser destacada a solução, relativamente moderada, prudente e razoável, dêsse particular, encontrada na constituição da O.I.T. (art. 7\% na sua redação atualmente em vigor), e que apenas confere assento "permanente", não-eletivo, no Conselho de Administração da Repartição Interna-

(7) A respectiva fórmula, baseia-se nas recomendações elaboradas por uma Comissão Especial presidida pelo Prof. ROBERTO AGo da Universidade de Roma, que sugeriram que (a) deveria ser assegurada a igualdade de tratamento a todos os Estados-Membros. independentemente da organização constitucional interna de cada um; e (b) deveria ser instituida una Junta de Apelação da Conferência, composta de três juristas independentes, a qual, por delegação da Conferência, caberia decidir, em única instância, os recursos interpostos pelos delegados que se julgarem prejudicados por não terem sido designados pelo respectivo grupo para integrarem as comissões, na qualidade de membro.

Veja-se também o artigo, de autoria de PIERRE VALline, chefe do grupo dos empregadores na O.I.T. intitulado "La Crise de l'Organization Internationale du Travail", publicado na revista francesa "Revue des Deux Mondes" de 1 de agôsto de 1959. 
cional do "írabalho aos 10 países-membros "de maior importância industrial", sendo que mais dez membros governamentais daquele órgão vêm sendo designados pelos demais delegados dos governos à Conferência.

Ressalvado êsse privilégio excepcional, prevalece na O.I.T. a plena iqualdade de todos os países-membros.

Valendo-se dessa norma, os seguintes dez países ocupam, no momento, os lugares permanentes naquele órgão executivo da O.I.T.:

Alemanha
Canada
China
Estados Unidos
França
Itália
India
Japão
Reino Unido
U.R.S.S.

Diga-se de passagem que a índole meramente estática dos critérios, relativos à definição dos países de "maior importância industrial", sem atenção suficiente dispensada aos elementos dinâmicos dos processos de industrialização, levoti à inoportuna e lamentável substituição do Brasil por outro pais naquele grupo privilegiado de nações, de vez que passou, na respectiva lista, ao décimo primeiro lugar.

Sob a impressão, possivelmente mal interpretada, da referida exclusão da categoria de membro permanente do Conselho, o Brasil, em consonância com as instruções do Govêrno, deixou de apresentar a sua candidatura nas respectivas eleições, tendo apenas nos ultimos anos reassumido, nessa forma, a sua posição naquele órgão "governamental" da O.I.T. de que, na realidade, fazia parte, quase ininterruptamente, nestes últimos quarenta anos.

D. Estrutura dos principais órgãos da O.I.T.

São três :

1. Conferência Internacional do Trabalho (8), órgão representativo, "para-parlamentar", de grau supremo da O.I.T., investido de podêres "legislativos" que reune em sessões periódicas ( 43 sessões até esta data), aproximadamente, 800 delegado, assessôres e conselheiros, que representam, sob a forma tripartidária, os países-membros.

(8) No aue diz respeito às bases jurdico-regulamentares dêsse órgão, é preciso consultar, independente das normas constitucionais, os dispositivos extremamente importantes do Regulamento da Conferência Internacional do Trabalho, adotado no dia 21 de novembro de 1919 e alterado, nesse meio tempo, 30 (trinta!) vêzes pelas reuniőes posteriores da C.I.T. 
De um modo particular, compete à Conferência :

a) adotar :

18) convenções; e

$\left.2^{\circ}\right)$ as recomendações : ambas formas da chamada legislação intercional de trabalho, por enquanto: 114 convençôes, das quais 92 em vigor, com o total de quase 1900 ratificações nacionais, e 112 recomendações; e

3) as resoluções :

b) eleger os membros do Conselho de Administração da R.I.T.;

c) examinar a aplicação pelos países-membros das convenções ratificadas ;

d) aprovar o orçamento da O.I.T. (em 1959 no montante total de 8.529.857 dólares americanos);

e) proceder à discussão livre, com participação dos Governos, empregadores, dos trabalhadores dos problemas atuais do panorama social, nacional e internacional, para o que serve de ponto de partida o Relatório anual apresentado à Conferência pelo Diretor-Geral da Repartição Internacional do Trabalho.

2). Conselho de Administração, órgão colegiado de caráter executivo, encarregado, sobretudo, de determinar a politica geral e o programa de atividades da Organização e supervisionar a R.I.T., integrado por 20 representantes dos governos (relembramos: metade de representantes dos países "de maior importância industrial" e outra metade proveniente das eleições periódicas trienais) assim como por 10 delegados dos empregadores e 10 dos trabalhadores.

Cabe-lhe, de um modo particular:

a) fiscalizar os trabalhos da Repartição Internacional do Trabalho;

b) exercer contrôle sôbre as diversas comissões e comités especiais ;

c) fixar a agenda da Conferência, se não determinada pela própria Conferência ;

d) elaborar o projeto de orçamento da O.I.T.;

e) eleger o Diretor-Geral da R.I.T., e

f) representar a O.I.T. em suas relações externas.

Realizou, por enquanto, 142 sessões.

3. Reparttção Internacional do Trabalho (R.I.T.), secretaria permanente, admunistrativa e técnica, da Organização, com sede em Genebra, que constitui o centro mundial de documentação e pesquisa, prepara os relatórios e questionarios necessários como base dos trabalhos normativos ou técnicos das conferencias, reuniōes e seminários, orienta os trabalhos de assistência técnica internacional, divulga estudos científicos e trabalhos comparativos, inclusive de indole legislativa, edita revistas e publicações periódicas, coleta dados cstatísticos e procede ao intercâmbio da política social. 
Dispõe de "escritórios locais" em 12 países e da rêde de "correspondentes nacionais" nos demais 13 paises-membros.

Em virtude da crescente regionalização das atividades da O.I.T. (6 conferências americanas, 4 asiáticas, 1 européia e 1 dos países do Oriente Próximc: e Médio, tôdas de caráter geral, ao lado de inúmeras reuniões específicas), vem sendo ampliada cada vez mais, a organização de Centros de Ação, sendo que, no momento, existem cinco :

18) de México (América Central, México e Antilhas);

2\%) de Lima (América do Sul);

3:) de Bangalore (Ásia);

4) de Istambul (Oriente Próximo e Médio); e

5) de Lagos (África).

Inportantes funções de caráter administrativo e representativo cabem ao Diretor-Geral da Repartição Internacional do Trabalho, designado para o periodu de dez anos, pelo Conselho de Administração.

O maior papel na história da O.I.T. desempenhou o primeiro Diretor, notável homem de estado francês, Albert Thomas (1919-1932).

Seus quatro sucessores foram :

Sir Harold Butler (1932-1938), inglês;

John C. WinANT (1938-1941), americano;

Edward J. Phelan (1941-1948) irlandês; e

DAvid A. Morse (1948), americano.

Entre as mais interessantes inovações organizacionais da O.I.T. destacam-se as "Comissões de Indústria", inauguradas a contar de 1945, que têr por objetivo examinar os problemas específicos de trabalho peculiares de cada setor da indústria, sendo que, atualmente, existem para dez ramos de ativiciades industriais.

\section{TÉCNICAS DE ATUAÇÃO DA O. I. T.}

A. "Legislação Internacional de Trabalho".

\section{a) Convenções}

Com o fim de fomentar a criação de um direito de trabalho, em sua essência. comum a vários estados, a O.I.T. promove a universalização das normas socrais, atinentes ao trabalho sensu lato e aos aspectos correlativos de indole social, sempre que possivel, sob a forma de maior eficácia jurídica, a de convenção.

Os compromissos convencionais obrigam os países que aderiram à convençãc: a aplicar as normas dai resultantes diretamente, isto é, sob a forma auto-aplicável, ou, bem - em função (a) da natureza dos dispositivos em 
questão e $(b)$ das particularidades constitucionais dos respectivos países através das normas da legislação nacional: leis, decretos legislativos, decretos ou outros atos juridicos de indole correlativa.

A convenção internacional de trabalho não diverge, quanto às suas principais características formais, de tôdas as demais convenções internacionais.

Não deve ser, ao nosso modo de ver, emprestada maior importância a uma determınada particularidade na sua origem, isto é, à falta da assinatura dos textos convencionais pelos plenipotenciários dos países, o que, via de legra, se piocessa em conferências diplomáticas de caráter internacional.

Conträriamente a essa praxe tradicional, a adoção das convenções efetua-se, de acôrdo com o que estatui o art. $19, \S 2^{\circ}$ da Constituição da O.I.T., mediante decisão da Conferência aprovada pela "maioria de dois têrços de votos emitidos pelos delegados presentes", veja-se bem, todos os delegados, i1idistintamente, tanto os governamentais como os "classistas".

Niessas condições, o voto - "pro", "contra" ou abstenção dos representantes dos governos não acarreta consequiência alguma, juridica ou mesmo politica e moral, quanto à futura ratificação, ou não, da convenção adotada.

E' nisto que consistem as principais funções normativas da Conferência, de que faz amplamente uso, embora num ritmo, com o tempo, um tanto diminuído: na "produção", reqular e sistemática, em condições de procedimento pormenorizadamente preestabelecidas, das convenções - forma, a que, en consonância com o disposto no art. $19, \S 1$, deve caber prioridade em iniciativas juridico-internacionais da O.I.T.

Quais são as obrigações que resultam para com os países-membros da aprcvação dá convenção?

En conformidade com o que estatui o art. $19, \S 5^{\circ}$ os paises-membros obrigam: (a) "a submeter a convenção... à autoridade ou autoridades às quais compete êsse assunto, para que lhe dêem forma de lei ou adotem outras medidas". (b) a informar a respeito o Diretor-Geral da O.I.T. (c) e "caso obtiver o consentimento da autoridade ou autoridades... a comunicar ao Diretor-Geral a ratificação formal da convenção e adotar as medidas rıecessárias para tornar efetivas as disposições da referida convenção".

A competente autoridade nacional à qual as convenções devem ser submetidas é - de acôrdo com o relatório de uma comissão especial da O.I.T'. (9) "O Poder Legislativo... quer dizer, o órgão que tem a faculdade para promulgar as leis para a aplicação das convenções".

Segundo um dos mais notáveis intérpretes das bases legais da O.I.T., LEON Eli Troulet, a autoridade em questão poderia ser tanto, no tocante aos podéres de "legislar", pormulgar "leis", porventura necessárias para dar cumprimento à convenção, o Poder Legislativo, isto é, o Parlamento, como

(9) Relatório da Comissão de Técnicos na Aplicação de Convenções". Informe III, parte IV da $35^{\circ}$ Sessão da C.I.T. de 1952, p. 9. 
Pocier Executivo, onde a separação de podêres não fôsse efetiva ou onde coubessem a êsse, atribuições específicas para adotar as disposições regulamentares de grau hieràrquicamente inferior, sôbre a matéria visada pela Convenção. (10)

Cumpre agora abordar o exame do panorama das obrigações estatais em duas hipóteses opostas acima aludidas, isto é, (a) de ratificação da convenção ou $(b)$ de falta de seu cumprimento.

Em primeiro caso, é preciso distinguir, por seu turno, duas situações diferentes : a de concordância — ou de discordância da legislação nacional com as normas internacionais, ora incorporadas, dessa forma, na ordem juridica interna.

$\mathrm{Na}$ primeira dessas duas situações, não recai sôbre o país-membro, nenbuma cutra obrigação - a não ser a limitação da sua autonomia legislativa no que diz respeito ao eventual abandono da solução nacional que corresponda aos respectivos compromissos - convencionais. De vez que tais retrocessos no âmbito das providências protetoras e tutelares ocorrem só excepcionalmente e, ùnicamente em épocas de profunda crise, a "estabilização internacional" das normas sociais internas tem expressão relativamente limitada.

$\mathrm{Na}$ segunda situação, torna-se necessário recorrer às providências normativas, ajustadas às particularidades de cada caso em aprêço, com o fim de readaptar o status quo legal às novas obrigaçóes de ordem internacional.

De um modo geral prevalece, como é notório, a opinião favorável à derrogaçãn automática "de pleno direito", pela convenção ratificada das normas leg!slativas anteriormente em vigor, que lhe fôssem contrárias. Contudo, os requisitos de ordem jurídica podem tornar oportuna a revisão expressa das mesmas por meio dos diplomas legais de caráter nacional.

Não pode deixar de existir certa latitude, quanto à forma pela qual essas normas têm que ser introduzidas no direito nacional, mediante revisão da legislação vigente - ou apenas através das convenções coletivas, sentenças arbitrárias, acôrdos individuais etc. Às vêzes, o próprio texto da convenção opta a favor de determinadas formas de incorporação de seu conteúdo na realidade social dos países que aderirem às suas obrigações.

O valor do direito internacional do trabalho, teria caráter precário e duvidoso se não competissem à O.I.T. amplas e incisivas atribuições, no que diz respeito à fiscalização do cumprimento pelos países-membros das normas convencionais.

$\mathrm{O}$ art. 22, obriga-se, pois, a apresentar à R.I.T. relatórios anuais sôbre as medidas adotadas para pôr em execução as convenções ratificadas.

Êsses relatórios - cujo total ultrapassou já a 5.000 ! - são objeto do exame cuidadoso por uma comissão especial de peritos e por uma comissão de aplicaşão de convenções e recomendações designada pela C.I.T., que

(10) "Législation Sociedade Internationale", Vol, I, p. 149. 
apresenta, a seguir, relatório ao plenário, a que cabe o pronunciamento final sôbre a procedência das observações críticas e das explicações dos respectivos governos.

Além do contrôle permanente de natureza administrativa, em que faltam, na realidade, sanções concretas, fora das pressões de caráter moral e politico, a Constituição dedica, nos artigos 24-34, muita atenção ao mecanismo jurisdicional, relacionado com a solução de "reclamações" (pelas organizações profissionais) e "denúncias" (pelos governos) apresentadas contra o não cumprimento por um determinado país de instrumento por êle ratificado.

Contudo, não vale a pena submeter à análise detalhada as regras processuais prcvistas nessa matéria - inclusive as atribuições das comissões especiais de inquérito e os podêres, entregues à Côrte Internacional de Justiça, pois, em grande parte, ficaram letra morta, nunca aplicada na prática, em yirtude dos obstáculos provenientes da defesa, legítima ou não, da soberania nacional contra a ingerência dos órgãos internacionais.

Se a convenção não fôr aprovada pela "autoridade competente", "não recairá söbre o respectivo Membro, outra obrigação, a não ser a de informar ao Diretor da O.I.T... sôbre o estado de sua legislação e a prática com referência aos assuntos tratados pela convenção, esclarecendo em que medida se executou, ou se pretende executar... qualquer das disposições da convenção... e indicando as dificuldades que impedem ou retardam a ratificação da referida convenção". (art. 19, § $5^{\circ}$ c).

No art. $35, \S 1$, a Constituição estatui a obrigação de aplicação das respectivas normas aos territórios não metropolitanos, inclusive fideicomissários, a não ser que as questões tratadas pela convenção constituam competência das autoridades do território ou "quando a convenção fôsse inaplicável devido às condições locais ou sob a reserva das modificações que fôssem necessárias para adaptá-la às condições locais".

A anlicabilidade condicional e limitada aos territórios dependentes do "Código lnternacional de Trabalho", constitui matéria altamente controvertida, tendo sido, ùltimamente, objeto de críticas reiteradas por parte dos ilustres representantes do Poder Legislativo brasileiro que participaram, na qualidade de "observadores", da Conferência Internacional de Trabalho, assim como dos membros da nossa delegação governamental a êsse conclave.

A posição das possessões coloniais e dos territórios de estatuto internacional congênere, dentro do âmbito da legislação internacional do trabalho, toca di perto às questões de universalidade e homogeneidade das legislações nacicnais, problemas mais vitais da Organização, que propomo-nos apreciar a seguir, a parte.

O que nos parece indispensável esclarecer, desde já, a essa altura, é que a referida questão diz respeito apenas à extensão pelos países metropolitancs às colônias, da vigência das normas internacionais "de aplicação geral". Ora, em vista das inevitáveis dificuldades que oferece, com freqüência, a observação dos respectivos compromissos pelos territórios dependentes, de economia social, via de regra, menos evoluída, a O.I.T. envcredou por um caminho diferente, dando preferência à adoção dos instru- 
mentos, separados e autônomos, reajustados, em sua essência, às condições aribientais das respectivas áreas, particularmente das situadas no Continente Africano.

O primeiro aspecto formal, que condiciona a eficiência jurídica das convenções, relaciona-se com a generalização de seus compromissos, evidenciada pelo número de ratificações nacionais.

Pois bem, continua extremamente precário o balanço de ratificações, sem atingir o total de 1.900 (1863 - no dia $1^{\circ}$ de janeiro de 1959, (das qua 3 450, isto é, quase um quarto de ratificações, efetuadas pelos países da Ámérica Latına).

Ora, multiplicando-se o número de convenções adotadas (114) pelo número de países-membros (80), chegamos ao total ideal de 9.120 , ao passo que o balanço de ratificações registradas até esta data, não perfaz muito. mais de um quinto daquele número: vinte e duas convenções não entraram em vigor [ , or não ter sido preenchido o requisito elementar de sua vigência, de vez̃ que não reuniram siquer o número minimo de ratificações exigido para. tal fim.

Nãu zdianta tentar apreciar o sucesso prático das convenções meramente sob o ângulo nominal e exclusivamente quantitativo da ratificações. nacionais. Varia muito de um caso para outro o "pêso" efetivo da. convenção medido pela extensão de seus compromissos. Maior adesão manifestam as convenções que não impõem maiores ou, até, quaisquer obriçaçôes sociais : 54 -ratificações da convenção n² 29 sôbre o trabalho forçado, 50 a $n^{\circ} 19$ sôbre a igualdade de tratamento na reparação dos acidentes de trabalho, 46 , da $n^{\circ} 11$, sôbre direito de associação na agricultura -. 47, da $n^{\circ} 80$, sôbre a redação das cláusulas finais das convenções, e assim por diante.

O valor intrínseco muito relativo das ratificações manifesta-se, outrossim, peia participação fortuita e casual dos países-membros na respectiva lista. A maior contribuição para a mesma não significa posição mais elevada na escala de progresso social - nem vice-versa. Vários paises pequenos consideram de bom alvitre ratificar "em bloco" o maior número possível dessas convenções, no intuito de lograr assim prestígio e popularidade internacional, sem. aliás, prestar sempre maior atenção à exeqüibilidade dos compromissos assumidos perante a O.I.T.

Ao passo que a Alemanha não ratificou mais de 34 convenções, a Áustria 34, os Estados Unidos 7 e o Japão 24, a Cuba aprovou 64 convenções, a Bulgária 66, a Nicaragua 30, o Uruguai 57 a República Dominicana 22 e a Argentina 53.

Existem casos de adesão absolutamente fictícia ao direito internacional do trabalho, p. ex., as convenções marítimas - dos países sem navegação mercantil ou até, sem costa maritima ou às convenções relativas aos territórios não metropolitanos dos países desprovidos de tais possessões ultramarinas.

De um certo modo, e própria definitione, as convenções internacionais de trabalho têm que consubstanciar níveis minimos de proteção social, sancionados internacionalmente, colocando-se entre as soluções adotadas pelos 
paises mais adiantados e os mais atrasados. Como é que deve porém ser determinada a exata distância entre a regulamentação internacional e a nacional - naqueles e nesses? Os compromissos internacionais destinam-se, de un mode todo particular, para beneficiar os paises socialmente menos avançados, pois para com os mais "progressistas", que já possuem as conquistas preconizadas, significam apenas a imobilização das mesmas contra as eventuais tentativas retrógradas. $O$ "minimo" a ser garantido e a vigorar, em tese, no mundo inteiro, pode ser interpretado de maneira muito divergente.

Às vêzes, adota-se em Genebra instrumentos que especificamente, já pela sua denominação formal, têm por propósito definir niveis modestos de proicção realmente minima. Assim, a última regulamentação da seguridade social, adotada pela $34^{a}$ sessão da C.I.T., de 1952 (convenção $n^{9}$ 102) determine "normas minimas" relativas a essa matéria, sem que, mesmo, tenha sido possivel aprovar, simultâneamente, de acôrdo com a intenção inicial, conclusões normativas atinentes às "normas superiores".

Ao lado da regulamentação territorial teòricamente universal, assumem, com o tempo, posição importante convenções de órbita de antemão mais limitada, aplicáveis - em vista da própria matéria, do campo pessoal, ou mesmo da esfera territorial, formulada expressis verbis - aos territórios politicamente dependentes e econômicamente menos evoluidos: convenções sôbre o trabalho forçado, ou sôbre o trabalho nas plantações; convenções relativaś à "população indigena e tribal", aos "trabalhadores indígenas", aos "territórios não metropolitanos", etc.

$\mathrm{O}$ que afeta, por seu turno, a eqüivalência dos compromissos sociais e dos correspondentes encargos, é a inclusão, bastante comum no texto das convenções de diversas cláusulas "escapatórias" e "derrogatórias" assim como, a freqüiente opção reservada aos países ligados pela convenção de aplicarem, a seu critério, apenas algumas partes prédeterminadas das obrigações convencionais. Em compensação, não está admitida pela Constituição a ratificação com "reservas".

Assim, se a legislação internacional de trabalho contribuiu, indubitàvelmente, para a universalização das providências protetoras e, até, para uma certa uniformidade de seus fundamentos, não parece ter reduzido substancialmente as diferenças quantitativas entre o alcance e o custo das mesmas. Muitu pels. contrário, e implicitamente, reconhece, no espírito realistico, por meio das diversas técnicas normativas acima aludidas, a justificação dessas diferenças.

Falta, aliás, uma balança, capaz de medir, com tôda a objetividade, a distância que separa sob êsse ponto de vista os diversos paises, e isto a desf eito dos estudos comparativos, bastante adiantados, da R.I.T., (11)

(11) Vejam-se, p. ex., os três inquéritos destinados à comparação internacional do custo da seguridade social, o primeiro de 1949 , o segundo de 1950 e 1951, e, enfim, o último, baseado nas respostas governamentais ao questionário de 1955 , e publicado no estudo, intitulato. "El Costo de la Seguridad Social, 1949-1954", Genebra, 1958.

Não fazemos acima referência a vários trabalhos comparativos de âmbito ainda muito mais amplo, levados a efeito pela R.I.T. no periodo interbélico. 
com relação ao magno problema de confronto internacional do custo da politica social.

Seria errada e exageradamente lisonjeira a interpretação do quadrn acima apresentado pela legislação internacional de trabalho, se nos levasse a supor que as obrigações convencionais vêm sendo realmente cumpridas, em sua plenitude e incondicionalmente, por todos os países-membros.

Infelizmente, é, com freqüência, considerável o hiato entre a letra das normas internacionais e a realidade social dos países que voluntàriamente aderiram às mesmas.

Basta passar em revista alguns dos aproximadamente 5.000 relatórios periódicos sôbre a aplicação das convenções, apresentados pelos respectivos Governos, para compreender os flagrantes defeitos que acusa a observação das disposições convencionais.

\section{b) Recomendações}

A maior parte das disposições relativas à legislação internacional de trabalho aplica-se, indistintamente, às convenções e às recomendações.

Existem certas diferenças doutrinárias quanto à conceituação jurídica de "Recomendação".

Vários autores atribuem-lhe caráter exclusivamente moral e não legal.

Essa tese parece-nos diminuir excessivamente e sem razão suficiente o valor dêsse ato, em que pese a falta (a) de obrigações especificas, quanto ao cumprimento das diretrizes que a recomendação sanciona e, por conseguinte, $(b)$ de quaisquer sanções em caso de infrações dos principios que preconiza.

O art. $19\left(\S 1^{\circ}\right)$ da Constituição estabelece uma visivel prioridade para as convenções, reservando a regulamentação às recomendações, caso a "questão tratada ou um de seus aspectos não se prestasse para a adoção de uma convenção".

A prática afastou-se, porém, um tanto da letra da disposipão acima reproduzida.

$\mathrm{Na}$ realidade, opta-se, realmente, a favor da recomendação em alguns casos, quando a própria natureza do assunto apreciado pela C.I.T., como sejam. p. ex., os serviços sociais de amprêsa, não reunam os requisitos mínimos exigicios para a adoção da solução convencional.

São, aliás, constantes os choques tradicionais entre os dois grupos classistas da Conferência na apreciação dessas modalidades alternativas da legislação internacional de trabalho. E' com certa monotonia que o grupo patronal tenta, quase sempre, reduzir o valor jurídico das decisões normativas da Conferência, pleiteando apenas a adoção de recomenciações, ao invés das convenções, advogadas, por sua vez, pelo grupo dos trabalhadores, com os raciocínios e argumentos que, novamente, pouco variam de uma para outra Sessão, e de um para outro caso. O grupo governamental costuma, 
via de regra, tomar, nesse particular, uma atitude intermediária, embora, na sua maioria, não negue preferência à adoção das convenções, inclinanco-se para o ponto de vista dos representantes dos trabalhadores.

Contudo, a maioria das recomendações têm caráter nitidamente diferente do acima aludido.

Vêm sendo adotadas como suplemento às vonvenções, simultâneamente adotadas - e não em substituição das mesmas. Nessas condições, a divisão da matéria, a ser codificada, efetua-se de tal modo que, em tese, a convenção, aprovada sepre com maior cautela, com vista às possibilidade de Suł ratificação, sanciona apenas algumas diretrizes, relativamente moderadas e de indole geral, ao passo que a recomendação consubstancia padrões mais elevados de proteção e regulamenta condições mais pormenorizadas de aplicação da solução internacionalmente preconizada.

Quais são os compromissos que impõe aos países-membros a adoção da recomendação?

A primeira, elementar, relaciona-se com a obrigação de submetê-la aos competentes órgãos nacionais: "à autoridade ou autoridades às quais compete o assunto a fim de lhe dar forma de lei ou adotar outras medidas" (art. 19).

Convém assinalar, nessa altura, a interessante divergência de opiniôes jurídicas entre os Ministérios das Relações Exteriores e do Trabalho, Indústrna e Comércio, no que diz respeito ao andamento, a ser dado pelo Govêrno em relação às Recomendações.

O Prof. Hildebrando Accioly opõe-se, no recente parecer, de autoria dŝle, à apresentação das mesmas pelo Govêrno ao Congresso Nacional, salientando que "não se destinam a criar compromissos internacionais".

Por outro lado, o parecer do Dr. ARnaldo Sussekind, procurador de trabalho (Parecer n: $1 / 59$, de 5 de janeiro de 1959 (processo M.T.I.C.-177.099-58), invocando normas constitucionais da C.I.T. c a sua interpretação por diversos órgãos oficiais, assim como pela doutrina de direito de trabalho internacional, defende a opinião que, de acôrdo com o direito constitucional brasileiro, as recomendações "devem ser submetidas ao Congresso Nacional, para que delas tome conhecimento e promova ou não, total ou parcialmente, a conversão de suas normas em lei brasileira, salvo se, excepcionalmente, versar sôbre matéria da alçada dos decretos executivos ou regulamentos - hipóteses em que ao Presidente da Repúblbica caberá adotar as medidas adequadas" (12)

A opinião do Ministério do Trabalho, Indústria e Comércio parece, aliás, corresponder plenamente ao ponto de vista formulado já pelo Consultor Geral da República (no Parecer n 288-Z, de 28 de maio de 1957, no processo n' P.R. 10.807-57).

(12) O referido parecer foi aprovado em 3 de setembro de 1959, pela Comissão Permanente de Direito Social do Ministério do Trabalho, Indústria e Comércio. 
Seja como fôr, a referida divergência de opiniões em que. indiretamente, se opõem pontos de vista baseados em normas de direito político e constitucional nacional às teses que encontram fundamento no direito internacional, deverá ser dirimida, de modo definitivo, palo Consultor Geral da República.

Vejamos agora se existem - e, eventualmente, quais - consequiências do ato de apresentação da Recomendação pelo Govêrno à autoridade ou às autoridades competentes.

O inciso d) do item 6 do art. 19 esclarece expressamente que, salvo essa obrigação, "não recairá sôbre os Membros nenhuma outra obriģação", com única exceção, formulada a seguir, isto é, o compromisso de indole informativa: os relatórios periódicos a serem prestados ao Diretoz Geral da R.I.T. "sôbre o estado da legislação c a politica, no que diz respeito aos assuntos tratados pela Recomendação, precisandorse, de que modo foram postas em execução, ou se propõe pôr em execução as disposições da Recomendação, assim como as modificações que se considera, ou se possa considerar necessário fazer nessas disposições (scil. = do direito nacional) para adotá-las e aplicá-las".

\section{B. Assistência Técnica Internacional}

Este setor das atividades da O.I.T'., formou-se na última década, na ampla arena internacional, conquistando, até, considerável prestigio, que parece resultar das esperanças, em parte excessivas, quanto às suas possibilidades práticas.

pressuposto essencial de todos êsses programas é a convicção de que é à falta de conhecimentos técnicos administrativos que deve ser atribuída - possivelmente ao lado de várias outras razões - o subdesenvolvimento das consideráveis e importantes áreas do mundo. Êsse pressuposto não pode ser aceito sempre como verdade axiomática.

Raramente basta a mera transferência dos paises mais evoluidos para os menos desenvolvidos dos recursos tecnológicos, não acompanhada pelo refôrço do equipamento e dos capitais, quase sempre necessários para a sua valorização.

De certo existem, no que diz respeito às questões sociais, que nos interessam aqui mais de perto, alguns setores, cuja solução oportuna requer particularmente elevados conhecimentos técnicos. P. ex., a introdução do seguro social implica em estudos prévios, subordinados ao propósito de estabelecer razoáveis previsões atuariais, com aproveitamento dos recursos estatísticos, das indicações biodemográficas e higiênicas, das informações sócio-econômicas, etc., e cuja devida apreciação pode criar dificuldades consideráveis em falta da experiència nacional prèviamente acumulada. Contudo, tais casos não apresentam, na realidade, freqüência extraordinária $\epsilon$ não parece caber ao subequipamento técnico dos serviços públicos maios respcnsabilidade pelo atraso do reformismo social, sobretudo em confrontc com tais fatôres como a escasséz dos recursos econômicos aproveitávei: para êsse fim. 
Os serviços técnico-assitenciais, prestados pela R.I.T. desde a sua inauguração, sofreram extensão considerável dentro do chamado Programa Ampliado de Assistência Técnica das Nações Unidas, pôsto em vigor em 1950.

No último exercício, o de 1958, as despesas com êsse programa a cargo da R.I.T. alcançaram a importância de 3.658 .513 dólares.

Pelas atividades técnico-assistenciais, em cujo desempenho foram utilizados 288 peritos e que abrangeram a concessão de 288 bôlsas, foram beneficiados, naquele ano, nada menos de 60 paises.

Dentro de órbita, extramamente diversificada, dêsse programa concede-se, atualinente, preferência aos setores relacionados com os aspectos sociais do desenvolvimento econômico, sobratudo mediante projetos devidamente integrados e de maior duração, com provával rendimento sócioeconômico, evitando-se a contraproducente dispersão que prevalecia nas primeiras fases.

Assim, em 1957, as atividades atinentes à mão de obra e formação profissional perfaziam $55 \%$ do programa, à produtividade $7,3 \%$, às cooperativas e pequanas indústrias $-9,9 \%$, à seguridade social $-4,4 \%$ e, enfin às condições de trabalho e administração dêsse setor - 22,9\%. (13)

E' extremamente difícil tirar do exame dos respectivos relatórios das missões da assistência técnica conclusões seguras a respeito da eficácia dos respectivos projetos, da proporção entre os bem sucedidos, os malogrados e os que ficaram sem maiores resultados, positivos ou negativos.

As observações pessoais do autor do presentz estudo, inevitàvelmente de cunho subjetivo e baseadas em impressões fortuitas, não parecem justificar uma opinião irrestritamente entusiástica a respeito do balanço dêsse programa.

A própria seleção dos projetos pelos governos assistidos nem sempre reflete uma compreensão plenamente amadurecida, pelos mesmos das vantagens que possa proporcionar ao pais interessado a solução que se tem em vista. Deixa muito a desejar a coordenação dos trabalhos de uma missão com os setores conexos, entregues às demais missões. Apesar do inconstestável progresso no recrutamento dos peritos. não faltam casos de designação para êsses cargos de enorme responsabilidade de pessoas que não preenchem tôdas as condições exigidas para seu bom desempenho. A constituição dos quadros meio-permanentes ("pool") do staff técnico internacional, a ser aproveitado sistemàticamente em trabalhos assistenciais, não manifesta progressos desejáveis.

Em vários casos não foi possível evitar choques ou atritos resultantes das interferências políticas, magistralmente expostos no recente estudo de autoria de um escritor nacional. (14). Apresenta, com freqüência, certas deficiências o sistema de cooperação entre as missões internacionais e os

(13) Em 1958 a proporção acima assinalada ficou quase intacta.

14) Georges D. Landau - Politica Internacional c Assistência Técnica, "Revista Brasileiro de Politica Internacional", Ano II, $n^{2}$ 6, de junho de 1959, pp. 66-90. 
órgãos nacionais dos paises assistidos. Ora, do sucesso dêsse sistema, e, particularmente, da integaração harmoniosa nos respectivos trabalhos das turmas administrativas locais depende sempre o futuro ("follow up") dos projetos que, fatalmente, podem apenas ser orientados, na fase inicial, pelos peritos internacionais. Enfim, não foram ainda aperfeiçoadas as técnicas de avaliação criteriosa, pari passu ou ex post, dos resultados das missões.

Como tudo nos leva a crer, o uso criterioso dessas técnicas evidenciaria relativamente freqüentes casos de missões, cujos relatórios finais ficam simplesmente arquivados, sem exercer qualquer intluência palpável sôbre o progresso social dos "países beneficiados".

En! suma, se a assistência técnica prestada pela R.I.T. levou, incontestàvelmente, em vários casos a resultados imediatos compensadores (p. ex. criação do seguro social na Birmânia, campanha de produtividade na república de Israel, realizações agrícolas e artesanais do projeto indigenista nos 3 países da região do Altiplano Andino, etc.), é preciso acompanhar as atividades técnico-assistenciais dêsse órgão com a maior atenção, para tirar das mesmas as mais amplas vantagens, escoimando-as, em sua operação, dos defeitos, em parte acima assinalados.

Apreciando o balanço prático dêsse programa não podemos, todavia, esquecer que seu valor não depende ùnicamente da orientação da entidade assistencial, como também do modo em que sabem aproveitá-los, em prol do progresso social, os governos dos paises subdesenvolvidos.

\section{Outros setores de atividades da O. I. T.}

Merecem destaque particular os trabalhos cientificos e técnicos, de coleta dos dados, de sua sistematização e divulgação, levados a efeito pela O.I.T., e que, dada a crescente complexidade dos problemas sociais, assumem posição de importância cada vez maior.

$\mathrm{E}^{\prime}$ dificil imaginar atualmente quaisquer iniciativas nacionais de maior envergadura no setor em aprêço sem consulta dos respectivos relatórios elaborados por aquêle Ministério Internacional do 'Trabalho.

Não parece passivel de interpretação controvertida o alto nivel técnico dos trabalhos da R.I.T. no setor de pesquisa e estudo, inclusive quanto à civulgação de legislação nacional comparativa ("Série Legislativa"). Merecem particulares elogios, p. ex., as excelentes publicações relativas à atuária e à estatística. Nem todos os trabalhos doutrinários de caráter econômico reunem, por sue vez, os desejáveis padrões cientificos. Há nas respectivas atividades da R.I.T. algumas lacunas lamentáveis, p. ex., no que diz respeito ao estudo aprofundado dos institutos de proteção social à familia, setor fronteiriço entre a politica social e demográfica. Enfim, nota-se a ausência nos programas da R.I.T. de trabalhos dêsse gênero que possam apresentar interêsse todo particular para o Brasil sob o prisma dos problemas que enfrentam os no momento: participapão obrigatória nos lucros, salário minimo familiar e, de um modo geral, averiguação das funções não sòmente sociais, como também econômicas do salário minimo e do salário móvel. 